\title{
Consequences of bullying on university students in Bangladesh
}

Md. Mostafizur Rahman Assistant Professor

Department of Management, Hajee Mohammad Danesh Science and Technology University, Bangladesh-5200,

Ph.D. student, School of Management,

Huazhong University of Science and Technology, China. mostafiz@hstu.ac.bd, ORCID: 0000-0002-7668-4213.

Md. Monjurul Hasan, Independent Researcher,

Department of Management, Hajee Mohammad Danesh Science and Technology University, Bangladesh-5200, monjurulmohasin@gmail.com,

ORCID:0000-0002-4528-2772.

Md. Alamgir Hossain, Ph.D., (Corresponding author) Associate Professor,

Department of Management, Hajee

Mohammad Danesh Science and Technology University, Bangladesh-5200, shamimru@gmail.com,

ORCID: 0000-0002-8217-6610.

Md. Zahangir Kabir, Ph.D., Professor,

Department of Management, Hajee Mohammad Danesh Science and Technology University, Bangladesh-5200, zahangirhstu@yahoo.com, ORCID: 0000-0002-8641-3409.

\section{Introduction}

The true growth of an economy depends on the development of a nation and its citizens as human resources and higher education plays an inevitable role in such context. Bangladesh is not an exception to this. At existing there are greater than 46 public and 105 non-public universities in the country (UGC Bangladesh, 2020). Therefore, now what matters in this connection is not the number but the quality. Actually, the purpose of education is to bring economic, social, political, cultural development and also mental, environmental, physical development of human being. Institutions of the public sector in country are in utter disarray. Regularly increasing demand and inadequate facilities, and additionally the absence of conducive atmosphere in the campuses are driving away large number of students every year to our neighbouring country and elsewhere. To make surea higher cultural corporation want to advance congenial working surroundings for human resources. To address these issues, the organizations need to focus on uninterrupted education. 
Bullying in higher education is one of the reasons for disturbance. Bullying is the act of intimidating, threatening, and coercing in an offensive or aggressive manner. Another definition of bullying is when an individual ora group of people with more power, repeatedly and intentionally cause hurt or harm to another person or group of people who feel helpless to respond.A conflict cannot be called bullying if the incidents an isolated event or if two parties of approximately equal strength are in conflict (Einarsen and Skogstad, 1996; Zapf, 1999). Bullying isa one kind of violence. It involvesa real or perceived imbalance of power which affects the children or group of people who are less powerful (Olweus, 1999). According to a UNICEF report, 35\% of students in Bangladesh who have been bullied for one or more days in the last 30 days are between the ages of 13 and 15 or have been involved in a physical fight at least once in 2014 (Dhaka Tribune, 2018). It is one of the rising issues in Asia, including Bangladesh. Bullying and abuse have come to be a regular exercise in our country, leaving thousands of people each and every day fight to depression and the urge to stop their life.A very small quantity of find out about on bullying had been performed in Bangladesh. With regards to Bangladesh, Mahmood (2018) determined that in Dhaka city the children of Mirpur area are affirmed the experience of harassing ina huge range also, that show to outstanding classes of the city society. Along these lines, the proof of this investigation about tormenting in unnecessary school should be the concerning issue. Children are losing out of schools and girls are committing suicide due to bullying at schools. In UNESCO (2019) publisheda report that children who are frequently bullied are nearly three times more likely to feel like an outsider at school, and twice more probably to omit school in contrast to these who are no longer regularly bullied. Children bullied also have worse educational outcomes. Bully-victims are additionally nearly twice as probably to sense lonely, to be unable to sleep at night, and to have meditated suicide. It might also additionally play a serious role behind bad educational overall performance. Teachers and school authority lack of awareness and know how to address bullying in schools. In latest a long-time growing interest has been drawn to the phenomenon of 'bullying' in places of work and schools. At the present time the trend of bullying in workplaces and schools is increasing day by day. There is a developing physique of lookup on this issue, each in Finland and in many other nations (Analitis et al., 2009; Coleyshaw, 2010; Finnish School Health Inquiry, 2010; Keashly and Neuman, 2010). However, there appears to bea dearth of research regarding bullying at university level. Rahman et al. (2020) showed that the prevalence of workplace bullying in university. They chose the two universities namely HSTU and DIU and found that bullying has 
more in DIU than HSTU and presence are from 3\% to 30\%. The examination likewise found that some genuine occurrence of harassing is tended to in the two organizations. On the basis of present situation in Bangladesh about bullying, the study preferred to conducta study on consequences of bullying on university level students. The influencing factors of university bullying can be categorized based sampled university context and media context. Regarding university context, university environment is bullied by teacher, officers, student leaders, and friends who are generally relevant to university bullying. Maeng et al. (2020) examined use of danger evaluation fora statewide pattern of pupil threats towards instructors $(n=226)$ in contrast to threats in opposition to other students $(n=1,228)$. Results indicated that threats in opposition to teachers have been much less acquainted (15.5\%) than threats towards friends (84.5\%).

\subsection{Statistics of bullying is a serious issue}

The annual bullying survey (2018) in the UK 22\% students has been bullied and witnesses bullying. In the USA, the bullying rate are more than one out of every five (20.8\%) students report being bullied (National Center for Educational Statistics, 2016). In its observations, it has recently asked the UK, Denmark, Bangladesh to pay greater attention to the issue of bullying in schools (UNVC, 2006). In last July (2019), the High Court ordered the government to set up complaint boxes in educational institutions and to sensitize students to place complaints about discourteous, annoying and indecent behavior, and intimidation. Education Minister Dipu Moni stated "Ragging and bullying are frequent in all over the world however these do not go with the social values and education system of Bangladesh". Recently,a second-year student of EEE department of Bangladesh University of Engineering and Technology (BUET) was beaten to death by some students. (The Daily Star, 2019). More seriouslya college teacher who spoke against bullying was also murdered. The killings led toa series of protests across the country.

The media context is based on internet, e-mail, phone, message that are related to the student bullying in university. Many researchers show the evidence that media is related to the bullying. Accordingly, Coelho and Romao (2018) learn about results showed that (cyber) bullying roles strongly have an effect on social anxiety, social withdrawal and established the significance of inclusive of class dimension when examining the relation between bullying roles and social anxiousness and social withdrawal. 
The aim of the current study is to understand the consequences of bullying in university. Many researchers showed the negative effects of bullying on student education success and achievement. Kibriya et al. (2015) pronounced that harassing is considered asa significant trouble in educational settings all told components of the globe. In recent days, bullying isa very new concept for Bangladesh. Rather many myths are attached thereto. There do not seem to be more research work and there are not any perfect or standardized tools to live the bully victim among the kids, adults and university students in Bangladesh. In particular, the current study examines the consequences of bullying in university level students. Additionally, current study in an endeavor to explore the present scenario of bullying in HSTU, to identify the reasons of bullying, to measure the impact of bullying on performance, to identify the nature and degree of bullying, and to identify the solution for reducing the bullying in campus.

\section{Literature Review and Hypotheses Development}

\subsection{Background of the study}

The records of logical examination on casualty issues go back to the 1970s to the huge scope assignment of Olweus (Jimerson et al., 2009). As it has been logically researched on the grounds that 1970, it is practical to nation that managing menace/casualty issues is presently not another issue in the writing of brain science and schooling anyway it would seem that an everlasting issue. Harassing was first seen asa school-related issue which used to occur among companions and influencing their cooperation's with each unique and their future lives (Schenk and Fremouw, 2012). The scientists who analysed work environment harassing featured the terrible outcomes of tormenting practices. Accordingly, it is accepted that there is a need to look closer to the college understudies to discover how much they experience harassing to remember them. The investigations distributed that aside from rudimentary, auxiliary and secondary school understudies, college understudies (Tabak and Köymen, 2014) and the grown-ups who had vocations should be the domineering jerks, casualties or spectators. In the context of Bangladesh, though it exists in university students but researches regarding bullying issues are very limited. Research indicates that bullying gets so much more sophisticated and subtler in university. For this reason, we chose these topics for the study.

University bullying is a type of bullying that occurs in connection with education, either inside or outside of university. Bullying at university has 
various impacts, among such effect is the scholastic accomplishment. In this way, the current research is to determine the consequences of bullying on university level students.

\subsection{University environment and student bullying}

Pörhölä et al. (2019) posted that victims differed from these with no ride of bullying in that they reported higher of having current analysis of anxiousness syndrome and greater tiers of context-specific social anxiety in university studying contexts. The unique gaining know-how of conditions in which victims stated considerably greater tiers of social anxiousness have been seminars, discussions with their teacher, and taking assessments and tests. Lester (2013) found that when understudies sense that bullying might bea wonder in their school, they sense that they're risky which considered less occupied with class network. Hence, they need considerably less inspiration to attempt to do appropriately in school and that they do now pass on class exercises. The teachers' bullying is silently killing many students' educational profession making them reluctant about going to school (Fareo, 2015). In the context of Bangladeshi students of secondary level are regularly being bullied with the aid of their teacher in the classroom for their poor overall performance in English (Smith \& Brain, 2000). (Olweus, 1993) cautioned that bullying often takes place when there is little or no supervision such as school study room or surroundings. Alam (2017) recognized the forms of bullying in school such as kicking and hitting, locking internal the classroom, chance to physical beating and so on. As we are now dealing with the challenges of 21st century, we should provide significance to assemble our subsequent technology sound every bodily and psychologically. University bullying is a serious hassle for students in university which havea terrible lifelong impact on the students. University is continuously viewed as one of the most secure areas subsequent to home. Above review of literature concludes that university environment arise the student bullying. So, it can suggesta hypothesis that

Hypothesis 1: University environment encourages the student bullying experiences.

\subsection{Media factors and students bullying}

Honjo et al., (2011) identified two kinds of school bullying. There is the kind of school bullying as the place where no digital verbal exchange media 
are used (conventional kind of school bullying), as properly as the kind of school bullying where digital verbal exchange media (such as cell phone phones, quick messaging, emails, blogs, SNS, and BBS) are used amongst students in bullying (new kind of school bullying), and the authors reflect on consideration on school bullying the use of digital verbal exchange media (such as cell phones, SMS, emails, blogs, SNS, and BBS) and createa framework whose intention is to assist teachers discover whether or not school bullying is taking place amongst students.A survey in Japan (2009) reports that, SNS sites were used in about $78.4 \%$ of bullying incidents while BBS sites were used in about $8.5 \%$ of them.

Social media use has come to be a daily a part of the lives of teenagers. However, emerging issues related with SMU encompass frequent or extreme use, which may additionally detract from possibilities to take part in different positive activities, such as extracurricular and neighbourhood events (Jiang et al., 2012) and exposes young people to dangers for involvement in cyber-bullying and to greater aggressive on-line behaviour's, especially for boys (Craig et al., 2020). Carter (2013) analysed that cellular telephone and SNS are used to send email, SMS, immediately message for communicate however extra used create bullying for students. From above study it is understood that media factor is related to the student bullying. So, it can suggesta hypothesis.

Hypothesis 2: Media factors influence students bullying experiences.

\subsection{Students bullying and symptoms experience}

Mahmood (2018) found that there is a presence of tormenting in school level educators and understudies in Dhaka city result mental state like misery, outrage, uneasiness, despair and every once in a while, self-destruction. Brank et al. (2012) showed that bullying understudies are feeble, timid, and restless. They introduced that bullying students perform very poorly and they do not want to go to school to avoid bullying. Fekkes et al., (2006) validated that victims of bullying are increased possibly to decorate new psychosomatic and psychosocial troubles in contrast to youth who were no longer bullied. Bosworth et al. (2001) asserted that bullied students are continually depressed and are frequently crying for help. This review proved that student bullying experience supports higher levels of insecurity, anxiety, depression, loneliness, unhappiness, physical and mental symptoms. So, it can suggesta hypothesis.

Hypothesis 3: Students bullying is responsible for Symptoms experiences. 


\subsection{Education success and achievement and student bullying}

Kibriya et al. (2015) stated that bullying is a crucial problem that ought to have an effect on overall performance in school, which is oftentimes overlooked. They confirmed that bullying has an awful impact on academic performance. They moreover find out that woman students are greater affected with the aid of bullying. However, their comparison of the data showsa woman teacher in the classroom diminishes the negative impact of bullying on woman students. Young-Jones et al. (2015) proved that students are inclined to bullying after high school, and the results can negatively have an effect on college life, academic motivation, and educational outcomes. In addition, previous victimization can purpose educational difficulties for college students, even after the harassment has ceased. Van der Werf (2014) analysed bullying has short- or long-term effects on student's overall performance. She found that difference in bullying scholastic execution relying upon student's scholarly accomplishment. Murillo and Román (2011) found that hostility in schools badly affects instructive accomplishment in Latin America. They confirmed that the individuals who are genuinely or verbally influenced they perform ineffectively. On the basis of discussion, we saw that student academic performance and success are hampered by bullying. So, it can suggesta hypothesis for the student success and academic achievement.

Hypothesis 4: Education success and achievement are affected by student bullying.

\section{Methodology of the study}

The current study confined to 380 was randomly selected students out of 11000 students at HSTU. A well-structured questionnaire was developed in this study. The questionnaire comprises two portions namely demographic characteristics and bullying questionnaire. Bullying questionnaire was sub-divided into five categories: 1. university context questionnaire (UCQ), 2. media context questionnaire (MCQ), 3. students bullying questionnaire (SBQ), 4. symptom experiences questionnaire (SEQ) and 5. student's success and achievement questionnaire (SAQ). The UCQ was developed questionnaire based on university context and opinion of researchers and there are 8 items. The MCQ was developed based on bullying scale improvement for advanced education understudies: north Cyprus case (Doğruer, 2015) with 8 items. Therefore, some items were changed and cancelled based on the experience survey and current study context. SBQ was developed on the basis of Negative practices at work 
(bullying) one of the most mainstream size of harassing created by (Hoel and Cooper, 2000) trailed bya poll created in Norway by (Einarsen and Raknes, 1997) named 'The Negative Acts Questionnaire'- NAQ. NAQ was comprises of 29 things. For research purpose $15 \mathrm{NAQ}$ questions were used and only 4 items are taken after pilot study and factorization. The SEQ was based on an Evaluation of the Brief Symptom Inventory, for the purpose 18 items were converted into 6 and which is suggested by (Meijer et al., 2011). The SAQ were developed on the basis of the School Bullying on Students (Al-Raqqad et al., 2017) and experience survey with 8 items out of 21 (reduction after pilot study and factorization). The five-set questionnaire were designed uniquely on 7-point Likert scale (ranging from 1 to 7) strongly disagree to strongly agree. There were two consecutive pilot studies conducted to validate the instrument in the context of HSTU. The data were analysed using SPSS and AMOS-24. Some inferential statistics were used for analysing the data like factor analysis, descriptive statistics, correlation analysis, regression analysis, confirmatory factor analysis (CFA), exploratory factor analysis (EFA), and structural equation model (SEM) analysis. The reliability and validity of the data were also tested properly to ensure better acceptance.

To accomplish multivariate ordinariness and dispose of absent and erroneous reactions, 20 samples were taken out from the final tests. Noticing the significance of representativeness, we think abouta sum of 380 legitimate respondents from HSTU. Among the respondents, $56.6 \%$ were males, $43.4 \%$ were female. Table 1 presents a detailed view of respondent demographics including respondents' level, gender, and faculty.

Table 1. Demographic profile of the student $(N=380)$

\begin{tabular}{l|l|c|c}
\hline \multicolumn{1}{c|}{ Measure } & \multicolumn{1}{c|}{ Items } & Frequency & Percentage (\%) \\
\hline \multirow{2}{*}{ Level } & Level 1 & 5 & 1.3 \\
\cline { 2 - 4 } & Level 2 & 106 & 27.9 \\
\cline { 2 - 4 } & Level 3 & 46 & 12.1 \\
\cline { 2 - 4 } & Level 4 & 152 & 40.0 \\
\cline { 2 - 4 } & Masters & 71 & 18.7 \\
\hline \multirow{2}{*}{ Gender } & Male & 215 & 56.6 \\
\cline { 2 - 4 } & Female & 165 & 43.4 \\
\hline
\end{tabular}




\begin{tabular}{l|l|l|l}
\hline \multirow{2}{*}{ Faculty } & Business Studies & 48 & 12.6 \\
\cline { 2 - 4 } & Veterinary and Animal Science & 44 & 11.6 \\
\cline { 2 - 4 } & Fisheries & 38 & 10.0 \\
\cline { 2 - 4 } & Agriculture & 34 & 11.6 \\
\hline Computer Science and Engineering & 44 & 10.3 \\
\hline Science & 39 & 11.6 \\
\hline Social science and Humanities & 44 & 11.6 \\
\cline { 2 - 4 } & Engineering & 40 & 10.5 \\
\cline { 2 - 4 } & Post Graduate Studies & & 10.3 \\
\hline
\end{tabular}

Source: SPSS output

\section{Empirical results}

\subsection{Exploratory Factor Analysis of the Study}

At this phase of the examination, the items for university, media, bullying, symptom and success were analysed to discover the items for each gathering which would be utilized in the investigation to analyse the data. As a beginning stage, the factorability of the things was inspected. To see whether the "appropriation of qualities is sufficient for leading variable investigation" (George and Mallery, 2001), Kaiser-Meyer-Olkin (KMO) Measure of Sampling Adequacy and moreover Barlett's Test of Sphericity had been directed to check the "multivariate ordinariness of set disseminations" (George and Mallery, 2001). For the things of the survey the KMO record was 0.88 , which is more prominent than the cut-off worth and Bartlett's trial of sphericity was directed. The test uncovereda huge outcome, $\mathrm{x} 2(153)=2436.105, \mathrm{p}=.000<.01$, which demonstrated that the correlation matrix; in various words, objects had been adequately associated to stack on the components of the scale. To distinguish the scores for each factor of the things we utilized principal components analysis (PCA) which "is the default technique for factor extraction utilized in SPSS" (George and Mallery, 2001) was utilized. We utilized varimax turn for the variables. Eight items were eliminated as they did not load .50 or more on any factor at the beginning of the factor analysis, additionally another seven things were wiped 
out as they stacked on more than one factor. Afterward, when we analysed the things under each factor, we saw that, in spite of the fact that the scale was expected asa five-factor scale, the thing likewise stacked on each factor seemed, by all accounts, to be marked as five factors. At the point when five components were chosen as fixed numbers to be removed, six things beneath .60 were wiped out from the scale and another six things were disposed of, as they were stacked on various variables. In the last form of the things in the scale five variables were named as university with 3 items, media with 3 items, bullying experience with 4 items, symptom with 4 items and success with 4 items and the loadings of the items are given in table 2.

Consequently, a few things were dropped or conveyed to shape the last imitation of the survey. For this examination Cronbach alpha was utilized to discover the outcome consistency. At that point the inside consistency of each factor was analyzed utilizing Cronbach's Alpha ( $\alpha$ ) esteem. The Alpha value was more than 0.700 . The initial Eigen values was 32.835 for success, 10.327 for symptom, 8.503 for bullying experiences, 6.965 for university and 5.908 for media context.

Table 2. Rotated Component Matrix

\begin{tabular}{l|c|c|c|c|c}
\hline & Success & Symptom & Bullying & University & Media \\
\hline E2 & $\mathbf{0 . 8 1 1}$ & 0.183 & 0.077 & 0.072 & 0.097 \\
\hline E3 & $\mathbf{0 . 7 8 7}$ & 0.097 & 0.189 & 0.089 & 0.141 \\
\hline E1 & $\mathbf{0 . 7 8 5}$ & 0.238 & 0.108 & 0.150 & 0.119 \\
\hline E4 & $\mathbf{0 . 7 3 6}$ & 0.188 & 0.161 & 0.068 & 0.123 \\
\hline D3 & 0.185 & $\mathbf{0 . 7 5 6}$ & 0.177 & 0.027 & 0.032 \\
\hline D2 & 0.172 & $\mathbf{0 . 7 3 6}$ & 0.142 & 0.128 & 0.042 \\
\hline D1 & 0.080 & $\mathbf{0 . 7 3 1}$ & 0.212 & 0.076 & 0.165 \\
\hline D4 & 0.238 & $\mathbf{0 . 7 1 5}$ & 0.067 & 0.025 & 0.167 \\
\hline C4 & 0.057 & 0.187 & $\mathbf{0 . 7 9 2}$ & 0.108 & 0.079 \\
\hline C3 & 0.089 & 0.111 & $\mathbf{0 . 7 6 8}$ & 0.198 & 0.109 \\
\hline C1 & 0.177 & 0.126 & $\mathbf{0 . 7 0 1}$ & 0.156 & 0.190 \\
\hline C2 & 0.227 & 0.190 & $\mathbf{0 . 6 7 6}$ & 0.056 & 0.128 \\
\hline$-\cdots . \cdots$
\end{tabular}




\begin{tabular}{l|l|l|l|l|l}
\hline A1 & 0.169 & 0.031 & 0.090 & $\mathbf{0 . 8 0 0}$ & 0.123 \\
\hline A3 & 0.103 & 0.057 & 0.190 & $\mathbf{0 . 7 8 1}$ & 0.158 \\
\hline A2 & 0.032 & 0.130 & 0.156 & $\mathbf{0 . 7 3 4}$ & 0.167 \\
\hline B1 & 0.114 & 0.117 & 0.137 & 0.088 & $\mathbf{0 . 7 8 0}$ \\
\hline B2 & 0.113 & 0.235 & 0.140 & 0.196 & $\mathbf{0 . 7 2 4}$ \\
\hline B3 & 0.198 & 0.021 & 0.161 & 0.212 & $\mathbf{0 . 6 9 7}$ \\
\hline Variance explained & 32.835 & 10.327 & 8.503 & 6.965 & 5.908 \\
\hline Cronbach's Alpha & 0.847 & 0.784 & 0.794 & 0.740 & .702 \\
\hline
\end{tabular}

Note. Bold letters are factor loading. $\mathrm{n}$ method = principal components analysis; rotation method $=$ varimax with Kaiser normalization. Rotation converged in 10 iterations.

Source: own study

\subsection{Confirmatory Factor Analysis}

Confirmatory Factor Analysis was directed to the items (university, media, bullying, symptom and success) utilizing AMOS, after the Exploratory Factor Analysis was finished. Confirmatory Factor Analysis is a factual method used to approve the factor structure of set noticed factors (Arbuckle, 2007).

\subsubsection{Scale Validation: Measurement Model}

To test the legitimacy of the measurement model, confirmatory factor investigation was directed. The first step was to look at merged legitimacy by examining each heap of a solitary thing. The standardized estimate of each construct is significant at the 0.001 level. In our examination, all things stacked well over 0.70 (aside from 7) for the develop to which they havea place, there by surpassing the recommended limits esteem (Hair et al., 2010; Fornell and Larcker, 1981). From that point, we inspected the construct reliability of each construct through composite reliability (CR), average variance extracted (AVE), and Cronbach's alpha. All were above limits, with values over 0.45 for AVE, over 0.70 for $C R$, subsequently speaking to great inward consistency in the measurement model (see table 3). Figure 1 subtleties measurement objects with separate normalized factor loadings of the measurement model. 


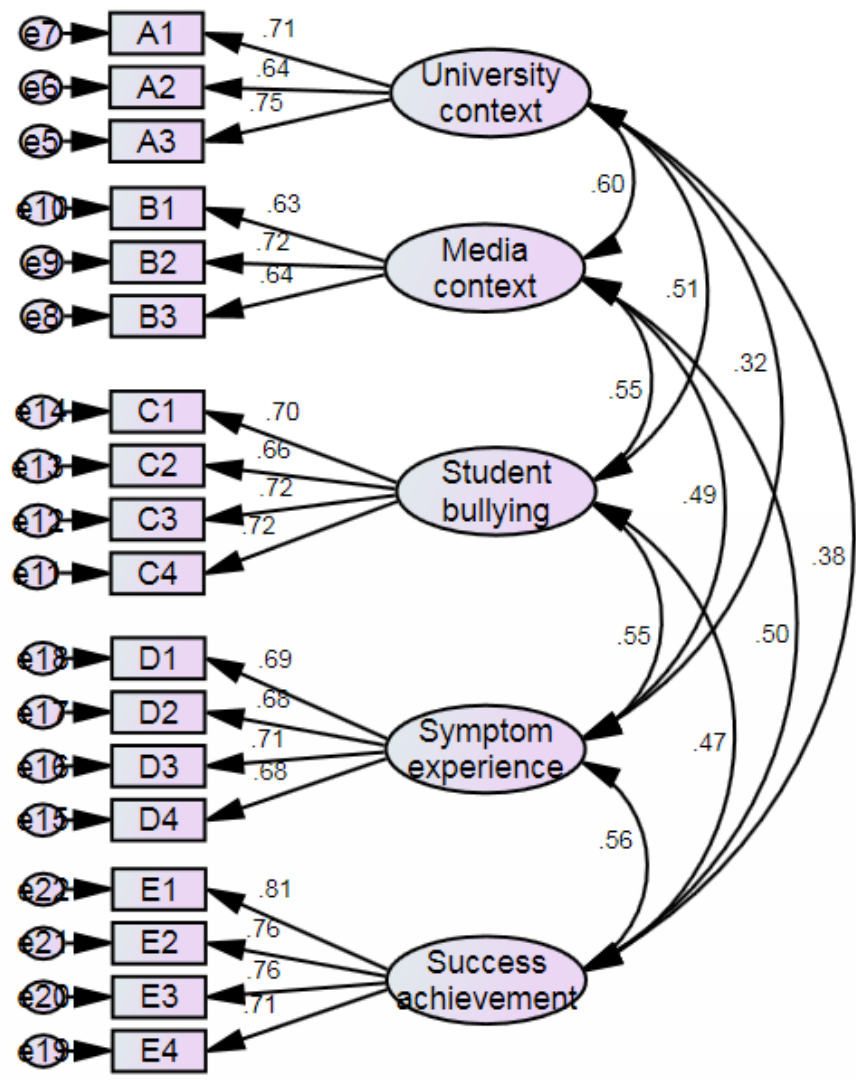

Figure 1. Measurement Model analysis

Source: own study

The results of discriminant validity test are shown in table 3, where the values on the diagonal are the square roots of the AVE for each variable, and the rest of the values are the correlation between each pair of variables. Square roots of the AVE for individual variables are higher than the correlation coefficients for other variables, which show the discriminate validity of the model. Additionally, multicollinearity among the predictor variable is examined through the variance 
inflation factor (VIF); values range from 1.29-1.44, which are below the threshold of 10 , representing an acceptable level.

Table 3. Discriminant validity

\begin{tabular}{l|c|c|c|c|c|c|c|c|c|c|c}
\hline $\begin{array}{l}\text { Con- } \\
\text { struct }\end{array}$ & Mean & $\begin{array}{c}\text { Std. } \\
\text { Devia- } \\
\text { tion }\end{array}$ & CR & AVE & $\begin{array}{c}\text { Uni- } \\
\text { versity }\end{array}$ & $\begin{array}{c}\text { Me- } \\
\text { dia }\end{array}$ & $\begin{array}{c}\text { Bully- } \\
\text { ing }\end{array}$ & $\begin{array}{c}\text { Symp- } \\
\text { tom }\end{array}$ & $\begin{array}{c}\text { Suc- } \\
\text { cess }\end{array}$ & $\begin{array}{c}\text { Tol- } \\
\text { er- } \\
\text { ance }\end{array}$ & VIF \\
\hline $\begin{array}{l}\text { Univer- } \\
\text { sity }\end{array}$ & 3.23 & 1.65 & 0.74 & 0.50 & $\mathbf{0 . 7 0}$ & & & & & 0.75 & 1.32 \\
\hline Media & 3.88 & 1.39 & 0.70 & 0.45 & 0.597 & $\mathbf{n / a}$ & & & & 0.71 & 1.40 \\
\hline Bullying & 3.49 & 1.53 & 0.80 & 0.50 & 0.511 & 0.553 & $\mathbf{0 . 7 0}$ & & & 0.69 & 1.44 \\
\hline $\begin{array}{l}\text { Symp- } \\
\text { tom }\end{array}$ & 4.19 & 1.47 & 0.78 & 0.49 & 0.315 & 0.490 & 0.546 & $\mathbf{0 . 7 0}$ & & 0.77 & 1.29 \\
\hline Success & 4.11 & 1.54 & 0.85 & 0.50 & 0.382 & 0.500 & 0.470 & 0.565 & $\mathbf{0 . 7 0}$ & & \\
\hline
\end{tabular}

Note: CR; composite reliability, AVE; average variance extracted, the bold letters are the square root of AVEs

Source: SEM-AMOS and SPSS output

While evaluating the attack of every part of the measure, a few files of fit, Comparative Fit Index (CFI), the Goodness-of Fit Index (GFI), Root Mean Square Residual (RMSEA) and PCLOSE were finished. In the investigation for the Goodness-of Fit Index (GFI), the qualities range somewhere in the range of 0 and 1.0, and 0 showsa poor fit and .90 demonstratesa brilliant fit. For solid match the Comparative Fit Index (CFI) should be .90 or even ideally .95 or above. Root Mean Square Residual (RMSEA) to be a solid match it is proposed to be 0.05 and lower or even 0.06 or lower. PCLOSE, which is a significance test fora close fit, shows whether the null hypothesis that the RMSEA is significant at the level less than .05. In order for an accurate fit $\mathrm{P}$ wants to be larger than .05

In the wake of confirming the validity and reliability measurements, this examination surveys model fit files, which is appeared in table 4 . The by and large the proportion of chi-square to levels of opportunity is significant (CMIN/ d.f. $=1.40, p=0.02$ ), which is inside their standard worth. Any remaining integrity of fit files are likewise inside the worthy reaches (CFI $=0.97$, GFI $=0.95$, AGFI = 0.93, NFI = 0.92, TLI=0.97, IFI 0.97 and RMSEA =0.03). All the fit lists speak to that the proposed model showsa sensibly decent fit to the data (Hu and Bentler, 1999; Hair et al., 2010). 
Table 4. Model fit indices

\begin{tabular}{l|c|c}
\hline \multicolumn{1}{c|}{ Item } & Standard value & Measurement model \\
\hline p-value & $\geq 0.05$ & 0.02 \\
\hline $\begin{array}{l}\text { The ratio of chi-square to degrees of freedom } \\
\text { (CMIN/df) }\end{array}$ & $<3$ & 1.40 \\
\hline Comparative fit index (CFI) & $\geq 0.90$ & 0.97 \\
\hline Goodness of fit index (GFI) & $>0.90$ & 0.95 \\
\hline Average GFI (AGFI) & $\geq 0.80$ & 0.93 \\
\hline Normalized fit index (NFI) & $\geq 0.90$ & 0.92 \\
\hline Tucker-Lewis index (TLI) & $\geq 0.90$ & 0.97 \\
\hline Incremental fit index (IFI) & $\geq 0.90$ & 0.97 \\
\hline Root mean square error of approximation (RMSEA) & $\leq 0.05$ & 0.03 \\
\hline p-close & $\geq 0.05$ & 0.99 \\
\hline
\end{tabular}

Source: amos output

\subsection{Scale Validation: Structural Model}

SEM is utilized to appraise the boundaries of the structural model and standardized solutions created by AMOS most extreme probability technique, which are appeared in table 5 . The model is evaluated by inspecting the path coefficients ( $\beta$ weights) which outline the quality of association among the constructs.

Having evaluated the measurement model, we built upa structural model to takea look at the hypothesized paths. The structural model used to be additionally proven to have an excellent model fit $\left(\mathrm{x}^{2} /\right.$ d.f. $=2.357$; RMSEA $=0.060 ; \mathrm{CFI}=0.924$; GFI=0.918; AGFI $=0.893 ; \mathrm{IFI}=0.924 ; \mathrm{TLI}=0.911$ ), with data in Table 5 . To inspect the structural model, we utilized the most extreme probability strategy: four out of four hypotheses were discovered to be significant and in accordance with our desires. Table 5 sums up the hypothesis results. The structural model demonstrates that $(\beta=0.594, p<0.01)$, and university $(\beta=0.306, p<0.001)$, significantly affect student bullying experiences thus hypothesis $\mathrm{H} 1$ and $\mathrm{H} 2$ are supported. 


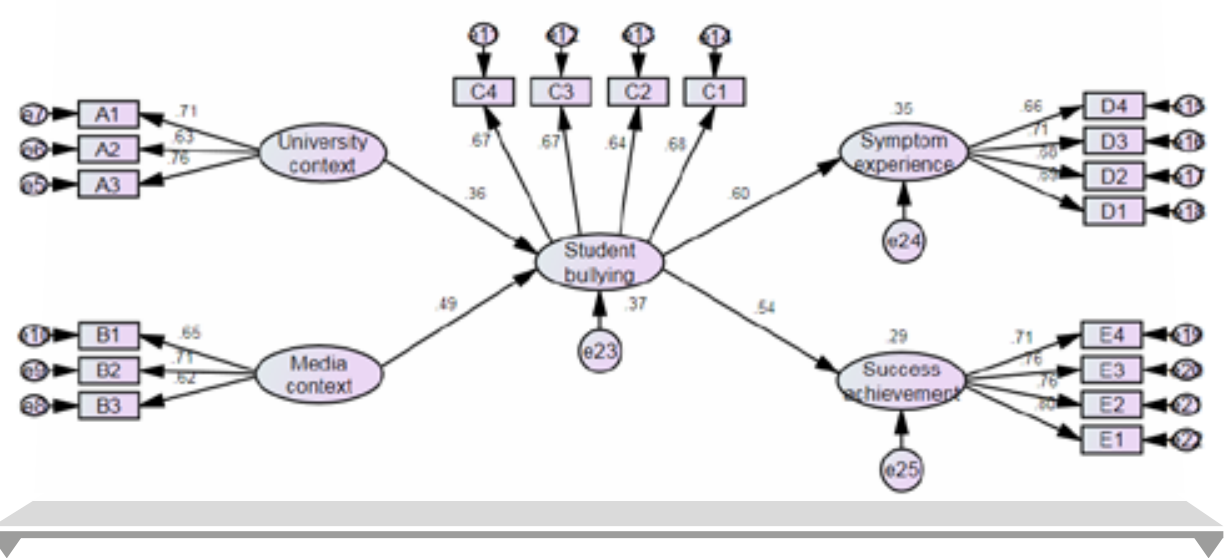

Figure 2. Structural model analysis

Source: own study

Student bullying experience show significant effects on symptom experience $(\beta$ $=0.545, \mathrm{p}<0.001)$ so hypothesis H3 is accepted. Furthermore, student bullying experience showsa significant influence on student success and achievement $(\beta$ $=0.525, \mathrm{p}<0.001$ ), which supports H4. The structural model explains $37 \%$ of the variance in student bullying experiences, 35\% of the variance in symptom experiences and $29 \%$ of the variance in student success and achievement with the consequences of bullying in university.

Table 5. Summary of Hypotheses Test

\begin{tabular}{l|c|c|c|c|l}
\hline \multicolumn{1}{c|}{ Path proposed } & Estimate & S.E. & C.R. & P & Hypotheses \\
\hline Media context---> Student bullying & 0.594 & .094 & 6.304 & $* * *$ & H1 accepted \\
\hline University context--->Student bullying & 0.306 & .057 & 5.357 & $* * *$ & H2 accepted \\
\hline Student bullying---> Symptom experience & 0.545 & .071 & 7.667 & $* * *$ & H3 accepted \\
\hline Student bullying---> Success achievement & 0.525 & .069 & 7.566 & $* * *$ & H4 accepted \\
\hline
\end{tabular}

Structural Model Fit Indices; CMIN/d.f.= 2.357, p=0.00 GFI=.918, CFI=.924, NFI=.876, RMSEA=.060. ${ }^{* * *} \mathrm{p}<0.001$, Variance Explained: R Squared Bullying 37\% Symptom 35\% Success $29 \%$.

Source: SEM-Amos output 


\section{Discussion}

This research was conducted to explore the consequences of bullying at university. Psychologist, educationists, researchers and policymakers in country may gain some insight about the problem and plan for further research or develop intervention strategies to address this bullying issue. In this part, researcher focused on answering and fulfilling the objectives of this research through describing the present scenario, nature, degree, and consequences of bullying at university. The present study finds that bullying is existence in the sampled university. It is logical to anticipate that victims would be worried and anxious in the surroundings in which the bullying took place. They might respond with avoidance behaviour (skipping university, avoiding certain locations at university, going for walks away and even being suicidal), extra aggressive behaviour (such as bringinga weapon to faculty for self-defences or retaliation), and negative academic performance. Ammermueller (2012) found that being harassed hasa fundamentally negative effect on present and future students' execution in school and Skapinakis et al. (2011) found that casualties were bound to report self-destructive considerations than were menaces. The longterm effects of university bullying are numerous, and can consist of sensitivity, anxiety, and depression. Recent statistics propose that the majority of students will experience bullying at some point in their academic careers.

By analysing the means the sample's responses, it is clear that bullying affects student's symptom experiences success the study result shows that media $(\beta=$ $0.594, p<0.01)$, and university $(\beta=0.306, p<0.001)$, significantly affect student bullying experiences. The study also explores that Student bullying experience significantly effects symptom experiences and student's success and achievement at $(\beta=0.545, p<0.001)$ and $(\beta=0.525, p<0.001)$. On the basis of Variance Explained: $R$ Squared, the study finds out that students bullying experiences are influenced by university context and media context at $37 \%$. According to (Sinkkonen et al., 2014) 5\% of the university students had experienced either indirect public bullying or direct verbal bullying on campus. The present study reflects that students bullying experiences influences student's symptom experiences at 35\% this result support the Bosworth et al (2001) "bullied students are continually depressed and are frequently crying for help" and student's success and achievement at 39\% which prove the logic of (Le et al., 2005; Kosciw et al., 2013; Kibriya et al., 2015) research that declare bullying leads to negative educational performance and lower incomes after school completion. Other important reasons that affect symptom experiences and student's success are undefined in the study. 


\subsection{Theoretical Contributions}

Based on the findings and considering the reality of the context of Bangladesh following may be recommended to address the existing situation. It additionally is encouraged that to adapt and improvea bully identification scale. For further study sample should be selected froma wider range of the population for covering more diversity which is needed to ensure representation of the population for generalization. Teachers and the university administration need to take different measures to reduce bullying. Teachers may coordinate with and talk to the bullied students. Different types of bullying intervention program need to be developed all over the country of Bangladesh. NGOs can seta few projects for menaces to alleviate the university bullying. NGO can run nationwide series of awareness workshops to build strong healthy physical and mental life of students of Bangladesh. The government should take legal action to prevent bullying.

\section{Conclusion}

Bullying is silently killing many students educational career making them reluctant about going to obtain higher education. Even the worse consequence creates whena student drops out the university to keep away from the bullied peers, teachers and environments. As the threatening is increasing day by day,a greater research should focus on this area. All the stakeholders together with university authority, teachers, students and parents should come ahead to handle this acute problem. Otherwise, a lot of developing buds will be spoiled silently each year due to the fact of the penalties of bullying.

The study aim was to identify the consequences of bullying in university level students and also tried to saw the nature and degree of bullying in university. The examination finds the presence of bullying in sampled university. The study explores that bullying is not notable term in Bangladesh fairly students face bullying in university in their daily lives.

The current study will enable these worried be aware of the most effective method to manage the issue of bullying and its apparent consequences on university students' achievement. It additionally enables the victims to understand how to keep away from being bullied. Research on university level students bullying is scarce in Bangladesh. Therefore, the study provides research based scientific evidence of the bullying in university. The results of this study will provide important insights for teachers, parents, university administration, practitioners, and students to act practicing against bullying. 
The study result shows that most of the students suffer bullying from their friends and teachers. At the same time the study shows that university environment and media directly increase the students bullying experiences. Consequently, students feel week, nervous, pain and hold off the students about consciousness of their success and achievement. Successively, the current study offers more perception to the idea that introduction to repeated bad behaviours at university might also have an inconvenient impact on the victim's psychophysical health. The study saw that victims were bullied because teachers had shown preference him/her to other students. Those behaviours make other students jealous and become to feel unjustified. They would assume that they are handled partially by means of teachers. Therefore, teachers have to consciously pay attention to every student impartially, so that any students don't feel their teacher is indifferent to them. The university administration could utilize the outcomes to regulate the results of harassing and their modes in university level. The examination recommends that if the university tends to the current results of this investigation, clearly, they could take care of certain issues with respect to the bullying. In the early 21st century, increasing attention has been given to the importance of university administration, instructors and parents appreciation and recognizing the symptoms of bullying (among both bullies and victims), and being geared up with techniques and equipment to address university bullying.

Limitation and Future Research Guidelines. Despite the fact that the examination is restricted to discover the consequences of bullying in any case, it is important to discover the explanations behind such rate to get more outcomes. The vast majority of the respondents of the examination were timid and reluctant to share the data concerning tormenting specifically about inappropriate behavior, educator harassing. Now and again they endeavor to disguise the events of tormenting and activities taken by utilizing him eventually of the hour of harassed with him or his/her companions. They have an inaccurate accept as true with that nothing ought to be took place effective however their data will impart to other people. In many occasions the respondents offer that tormented gripe are currently not tended to right by means of organization that is the reason they havea concern of done sharing data which make problematic in information assortment reasonably. The study area was confined to HSTU. The university selected for this study did not solely represent all the university and students.A larger and more exhaustive sample of all over Bangladesh will be needed for better result. The small number of focus groups makes the results of this study difficult to generalize because the sample size was only 380 
respondents that not represent the whole country. For getting insufficient fund, the study only conducted on the present students. If fund is getting more the study will be conducted on the teachers, officers, employees, ex-students, national level and the result will be more representable. The desirable application of the results of this research reality will makea valuable contribution to development at the national level. In line with this, it is recommended that future studies use a more representative of the university in order to better understand the wider range of approaches to university bullying.

\section{Summary}

Consequences of bullying on university students in Bangladesh Bullying at university is a pervasive phenomenon that has negative outcomes on the psychological and actual wellbeing of students, their success and achievement. The examination expected to research the consequences of bullying on university level students. A self-administrated survey was planned by the exploration goals and theories. The sample size consists of 380 students randomly selected from different faculties of a public university in Bangladesh. The questionnaire was coded and analyzed using SPSS-AMOS-24 and descriptive analysis, exploratory factor analysis (EFA), confirmatory factor analysis (CFA) and structural equation modeling (SEM) were used for data analysis. The results of the study indicated that bullying exists at the university and affects student's academic achievement and success, either by victims or the bullies. The bullied students resolved unpleasant situations using active or passive responses. This study discovers the causes and consequences of students bullying and gives suggestions to the students, university administration and parents of students on how to solve this problem. The study also helps prevent bullying by educating student about their rights, providing students with confidential way to report bullying, encouraging bystanders by to take immediate actions, such as speaking up and reporting the incident and emphasizing the importance of family involvement. This study has recommended that teachers and the university administration need to take different measures to reduce bullying. Teachers may coordinate with and talk to the bully's students. Teachers, university administration, and NGOs can seta few projects for menaces to alleviate the university bullying. 
Moreover, the government should take legal action to prevent bullying. Therefore, the desirable application of the results of this research reality makesa valuable contribution to development at the national level.

Keywords: HEIs, university student, bullying, symptom, academic achievement.

JEL: $\quad$ A23, I230, I280

\section{References}

Alam, R. A. (2017). Exploring effects of teacher bullying on secondary English language learning in Dhaka (Doctoral dissertation, BRAC Univeristy).

Al-Raqqad, H. K., Al-Bourini, E. S., Al Talahin, F. M., \& Aranki, R. M. E. (2017). The Impact of School Bullying on Students' Academic Achievement from Teachers Point of View. International Education Studies, 10(6), 44-50. Ammermueller, A. (2012). Violence in European schools:A widespread phenomenon that matters for educational production. Labour Economics, 19(6), 908-922.

Analitis, F., Velderman, M. K., Ravens-Sieberer, U., Detmar, S., Erhart, M., Herdman, M., \& Rajmil, L. (2009). Being bullied: associated factors in children and adolescents 8 to 18 years old in 11 European countries. Pediatrics, 123(2), 569-577.

Arbuckle, J. L. (2007). Amos 16.0 [computer software]. Chicago, IL: Smallwaters.

Brank, E. M., Hoetger, L. A., \& Hazen, K. P. (2012). Bullying. Annual Review of Law and Social Science, 8, 213-230.

Carter, M. A. (2013). Protecting oneself from cyber bullying on social media sites-a study of undergraduate students. Procedia-Social and Behavioral Sciences, 93, 1229-1235.

Coelho, V. A., \& Romao, A. M. (2018). The relation between social anxiety, social withdrawal and (cyber) bullying roles:A multilevel analysis. Computers in Human Behavior, 86, 218-226.

Coleyshaw, L. (2010). The power of paradigms:A discussion of the absence of bullying research in the context of the university student experience. Research in Post-Compulsory Education, 15(4), 377-386.

Craig, W., Boniel-Nissim, M., King, N., Walsh, S. D., Boer, M., Donnelly, P. D., ... \& Van den Eijnden, R. (2020). Social media use and cyberbullying:a cross-national analysis of young people in 42 countries. Journal of Adolescent Health, 66(6), S100-S108.

DhakaTribune,(2018)https:/ / www.dhakatribune.com/bangladesh/ nation/2018/09/06/unicef-35-of-students-face-bullying-in-bangladesh. 
Doğruer, N. (2015). Bullying Scale Development for Higher Education Students: North Cyprus Case (Doctoral dissertation, Eastern Mediterranean University (EMU)-Doğu Akdeniz Üniversitesi (DAÜ)).

Einarsen, S., \& Raknes, B. I. (1997). Harassment in the workplace and the victimization of men. Violence and victims, 12(3), 247-263.

Einarsen, S., \& Skogstad, A. (1996). Bullying at work: Epidemiological findings in public and private organizations. European journal of work and organizational psychology, 5(2), 185-201.

Fareo, D. O. (2015). Bullying in Nigerian secondary schools: strategies for counseling intervention. Educational Research and Reviews, 10(4), 435.

Fekkes, M., Pijpers, F. I., Fredriks, A. M., Vogels, T., \& VerlooveVanhorick, S. P. (2006). Do bullied children get ill, or do ill children get bullied?A prospective cohort study on the relationship between bullying and health-related symptoms. Pediatrics, 117(5), 1568-1574.

Finnish School Health Inquiry, (2010). School Health Conference, 24-25 August 2010, Tampere. http://info.stakes.fi/kouluterveyskysely/FI/ kouluterveyspaivat/index.htm.

Fornell, C. \& Larcker, D.F. (1981). Evaluating structural equation models with unobservable variables and measurement error. Journal of Marketing Research, 18(1), 39-50.

George, D., \& Mallery, P. (2001). SPSS for Windows step by step:A simple guide and reference. Boston: Allyn.

Hair, J. F., Black, W. C., Babin, B. J., Anderson, R. E., \& Tatham, R. L. (2010). Multivariate data analysis (Vol. 5, No. 3, pp. 207-219). Upper Saddle River, NJ: Prentice hall.

Hoel, H., \& Cooper, C. L. (2000). Destructive Conflict \& Bullying at Work. Manchester: Manchester School of Management, University of Manchester, Institute of Science and Technology.

Honjo, M., Hasegawa, T., Hasegawa, T., Mishima, K., Suda, T., \& Yoshida, T. (2011, October).A framework to identify relationships among students in school bullying using digital communication media. In 2011 IEEE Third International Conference on Privacy, Security, Risk and Trust and 2011 IEEE Third International Conference on Social Computing (pp. 14741479). IEEE.

Hu, L. T., \& Bentler, P. M. (1999). Cutoff criteria for fit indexes in covariance structure analysis: Conventional criteria versus new alternatives. Structural equation modeling:a multidisciplinary journal, 6(1), 1-55.

Japan, (2009) Education Office, Saitama Prefecture, Japan, "Prevention of Cyberbullying Issues and Response Mannual,".

Jiang, X., \& Peterson, R. D. (2012). Beyond participation: The association between school extracurricular activities and involvement in violence across generations of immigration. Journal of youth and adolescence, 41(3), 362-378. 
Jimerson, S. R., Swearer, S. M., \& Espelage, D. L. (Eds.). (2009). Handbook of bullying in schools: An international perspective. Routledge.

Keashly, L., \& Neuman, J. H. (2010). Faculty experiences with bullying in higher education: Causes, consequences, and management. Administrative Theory \& Praxis, 32(1), 48-70.

Kibriya, S., Xu, Z. P., \& Zhang, Y. (2015). The impact of bullying on educational performance in Ghana:A bias-reducing matching approach (No. 3302016-13478).

Kosciw, J. G., Palmer, N. A., Kull, R. M., \& Greytak, E. A. (2013). The effect of negative school climate on academic outcomes for LGBT youth and the role of in-school supports. Journal of School Violence, 12(1), 45-63.

Le, A. T., Miller, P. W., Heath, A. C., \& Martin, N. (2005). Early childhood behaviours, schooling and labour market outcomes: Estimates froma sample of twins. Economics of Education Review, 24(1), 1-17.

Lester, J. (2013). Bullying in higher education: What current research, theorizing, and practice tell us. In Workplace bullying in higher education (pp. 15-36). Routledge.

Maeng, J. L., Malone, M., \& Cornell, D. (2020). Student threats of violence against teachers: Prevalence and outcomes usinga threat assessment approach. Teaching and Teacher Education, 87, 102934.

Mahmood, S. (2018). Nature and consequences of bullying at high schools in Dhaka city (Doctoral dissertation, University of Dhaka).

Meijer, R. R., de Vries, R. M., \& van Bruggen, V. (2011). An evaluation of the Brief Symptom Inventory-18 using item response theory: Which items are most strongly related to psychological distress?. Psychological assessment, 23(1), 193.

Murillo, J., \& Román, M. (2011). Latin America: school bullying and academic achievement. CEPAL Review.

National Center for Education Statistics. (2016). Indicators of School Crime and Safety: 2016. U.S. Department of Education. Retrieved from https:// nces.ed.gov/pubs 201017064.pdf.

Olweus, D. (1993). Bully/victim problems among schoolchildren: Longterm consequences and an effective intervention program.

Olweus, D. (1999). Bullying at school: basic facts and an effective intervention programme. J Child Psychol Psychiatry Allied Disciplines 1994; 35:1171-1190.

Özkiliç, R. (2012). Bullying toward Teachers: An Example from Turkey. Eurasian Journal of Educational Research, 47, 95-112.

Pörhölä, M., Almonkari, M., \& Kunttu, K. (2019). Bullying and social anxiety experiences in university learning situations. Social Psychology of Education, 22(3), 723-742.

Rahman, M. M., Islam, M. R., \& Kabir, M. Z. (2020). Prevalence of Workplace Bullying in University. International Journal of Asian Social Science, 10(1), 94-106. 
Schenk, A. M., \& Fremouw, W. J. (2012). Prevalence, psychological impact, and coping of cyberbully victims among college students. Journal of school violence, 11(1), 21-37.

Sinkkonen, H. M., Puhakka, H., \& Meriläinen, M. (2014). Bullying ata university: students' experiences of bullying. Studies in Higher Education, 39(1), 153-165.

Skapinakis, P., Bellos, S., Gkatsa, T., Magklara, K., Lewis, G., Araya, R., ... \& Mavreas, V. (2011). The association between bullying and early stages of suicidal ideation in late adolescents in Greece. BMC psychiatry, 11(1), 22. Smith, P. K., \& Brain, P. (2000). Bullying in schools: Lessons from two decades of research. Aggressive Behavior: Official Journal of the International Society for Research on Aggression, 26(1), 1-9.

Tabak, F. S., \& Köymen, Ü. (2014). Student experiences with cyberbullying in northern Cyprus. Procedia-Social and Behavioral Sciences, 116, 5200-5209. The annual bullying survey (2018). The Annual Benchmark Of Bullying In The United Kingdom.https://www.ditchthelabel.org/researchpapers / the-annual-bullying-survey2018/?gclid=Cj0KCQiAvc xBRCYARIs AC5QT91HYzCS_qKmOHIiLoV9OvFGdMik61cR_ kGQq92ZGrF6ClyMsbrH9PMaAtyCEALw_wcB.

The daily star, (2019). https://www.thedailystar.net/city/socialmovement-curb-ragging-culture-which-cause-buet-student-abrar-deathdipu-moni-says-1811917

UGC Bangladesh, (2020). http://www.ugc-universities.gov.bd/privateuniversities

UNESCO, (2019). Behind the numbers: ending school violence and bullying. https://books.google.com.bd/books/about/Behind_the_ numbers.html?id=nruHDwAAQBAJ\&redir_esc=y

Van der Werf, C. (2014). The effects of bullying on academic achievement. Revista Desarrollo y Sociedad, (74), 275.

Young-Jones, A., Fursa, S., Byrket, J. S., \& Sly, J. S. (2015). Bullying affects more than feelings: The long-term implications of victimization on academic motivation in higher education. Social psychology of education, 18(1), 185-200.

Zapf, D. (1999). Organisational, work group related and personal causes of mobbing/bullying at work. International journal of manpower. 